\title{
NEW TECHNOLOGIES AND ELECTIONS: SHOULD THE STATE PLAY ANY ROLE IN COMBATING MISINFORMATION?
}

\section{CONTROLE DE CONTEÚDO E FOMENTO: HAVERIA UM DEVER ESTATAL DE COMBATE À DESINFORMAÇÃO NAS ELEIÇÕES}

\section{MARILDA DE PAULA SILVEIRA}

Master of administrative law and Ph.D. in public law from the Federal University of Minas Gerais. Coordinator of the graduate programs in electoral law at the School of Law of Brasília - EDB / IDP. Professor of the undergraduate program in administrative and electoral law of the School of Law of Brasília - EDB / IDP. Professor of the master's degree program in the of research Constitution and Society of the School of Law of Brasília - EDB / IDP. Leader in Network Research on Campaign Financing and Constitution. Founding member of ABRADEP (Brazilian Academy of Electoral and Political Law) and director of IBRADE (Brazilian Institute of Electoral Law). Partner of Silveira e Unes Advogados Associados and Regional Coordinator of the NGO Transparencia Electoral.

\section{ABSTRACT}

Given the paradigm shift caused by new technologies, should the State play any role in combating misinformation in elections? This is the question to be addressed in the research that will lead to the scientific article. Assuming that it is necessary to gauge how far misinformation has been tackled in the electoral process with the emergence of new technologies through jurisprudential research. After preliminary research into the Superior electoral Court (Tribunal Superior Eleitoral -TSE) case-law and into the twenty-seven regional electoral courts, the hypothesis is that misinformation was not addressed as a relevant object aimed at protecting the freedom of voting. The exception would derive from decisions on the improper use of media (article 22 of LC 64/90). Restricting the disclosure of facts that are knowingly untrue or false advertising 
was more concerned with the protection of individual rights (such as the right of reply, image and honor) than with freedom of voting. From this analysis, we will try to understand how new technologies may potentially influence the freedom of voting based on how previous bibliographical research assessed the impact of misinformation brought by traditional media. Given the result, we propose to assess what has been presented as an alternative to deal with this new scenario of misinformation and whether the State has another role in this task beyond the jurisdictional and executive functions in public education policies. One possible approach would be the strategy of incentivizing actions by stakeholders aimed at broadening the voters' capacity to dialogue with all information they receive. Without searching an actor to stand as judge of truth.

KEYWORDS: Misinformation; Election; Judge of truth; Freedom of voting; Technology.

\section{RESUMO}

Diante da mudança de paradigma provocada pelas novas tecnologias, o Estado deve desenvolver algum papel no combate à desinformação nas eleições? Como pressuposto, entende-se necessário analisar como a desinformação foi tratada no processo eleitoral até o surgimento das novas tecnologias, o que se fará por meio de pesquisa jurisprudencial. A hipótese, após pesquisa preliminar na base jurisprudencial do TSE e dos vinte e sete tribunais regionais eleitoral, é de que a desinformação não foi tratada como objeto relevante voltado à proteção da liberdade do voto. A exceção ficaria por conta de alguns julgados que cuidam do uso indevidos dos meios de comunicação. A restrição à divulgação de fatos sabidamente inverídicos ou propaganda falsa voltava-se mais à proteção de direitos individuais (como no direito de resposta, a imagem e a honra) que à liberdade do voto. A partir dessa análise, verificar-se-á como as novas tecnologias têm potencial de influenciar a liberdade do voto a partir de levantamento bibliográfico que deu tratamento às mídias tradicionais. Avalia-se o que se apresenta como alternativa para lidar com esse novo cenário de desinformação e se o Estado tem outro papel além da função jurisdicional e do dever de desenvolver uma política pública de educação. 
PALAVRAS-CHAVES: Desinformação; Eleições; Juiz da verdade; Liberdade do voto; Tecnologia.

\section{INTRODUCTION}

The key question that drove the research of this article was the shift occured in the past two years, to the treatment of the impact of misinformation not only in Brazil, but throughout the world. This change is attributed to new communication technologies that are undoubtedly a disruptive factor in the access to knowledge and lead to the following questions: 1) how to define what misinformation is; 2) is misinformation confused with lies or fake news? 3) does the control of informational content deserve differential treatment during the elections? 4) is there a duty to combat misinformation? 5) whose duty is it? 6) is it necessary to define a judge of truth in this fight?

Faced with the perplexity imposed by the theme, the first challenge was to separate the wheat from the tare, giving specificity to the object of the analysis. The initial cut was made by centralizing the analysis specifically in the electoral process. Although some concepts and conclusions may be broadened to other decision environments, the methodological approach plays the important role in trying to prevent the analysis from ending up skewed.

Since the object of study was limited to the Brazilian electoral democracy, it was necessary to define the theoretical framework on which the work is supported. Given the understanding of the elements that make up democracy is not uniform, especially in the role of equality and freedom, it was necessary to establish the assumptions that will support the analysis.

Based on some consensus that decisions are legitimized by equality and freedom of choice, the way in which the will is formed becomes a key element in the quality of democracy. At this point we tried to evaluate to what extent misinformation interferes with the formation of the will. In order to do so, it was necessary to subdivide the elements of communication that may lead to this impact so that different issues are not treated indifferently. 
Given the definition that the claim to control misinformation is within the universe of content control, it was necessary to ascertain how misinformation has been handled by the control bodies so far in the electoral process.

From these data, it was possible to point out and propose - with no pretension to exhaust them - some instruments that would reduce the negative impact that misinformation produces in the decision-making process that stems from the formation of the voter's will, reducing the freedom of voting and, in effect, the quality of democracy.

\section{THE FORMATION OF THE WILL AS A CENTRAL ELEMENT OF DEMOCRACY}

The definition of the elements that guarantee the highest quality of democracy is not consensus among scholars. The divergence runs through the very concept of democratic state (DAHL, 2001; SARTORI, 1987), the extension of the guarantees of freedom and equality ${ }^{1}$ and the forms of implementation (DAHL, 2001). ${ }^{2}$

By putting together some consensus, Robert Dahl (2006) points out indispensable factors for forming a Democracy: the existence of elected representatives in free, fair and frequent elections; freedom of expression; the existence of alternative sources of information; autonomy to associate citizens in the search for the exercise of Political Power and the inclusion of all adult members of the body politic in the process.

\footnotetext{
1 Since Aristotle that gives prevalence to equality summarizing the characteristics common to all democracies as being: "Choice of high officials for all and among all; government of each for all and among all; government of each one for all and for each one in turn; choose by lot for all public functions, or for all those who do not require experience; abolition of qualification for possessions for the exercise of public functions; or its reduction at a very low level; prohibition of the exercise of public office for the second time, or more than a few times, by the same person, with few exceptions, except for military functions; exercise of public functions for short periods ...; the exercise of judicial functions by all citizens, that is to say, persons chosen from all, and in all, or most, serious and important matters; [...] payment for the exercise of public functions, preferably in all of them". (ARISTÓTELES, 1985, p. 1317a-1318b). ${ }^{2}$ Participatory democracy, identified with an American movement in the 1960s, condemns the distance between governors and the governed, insisting on the centrality of civic participation. Deliberative democracy, founded in the 1990s, fuses deliberation with public opinion and proposes that elections should not be the central point in the exercise of democracy - with the choice of representation - but that the participation of civil society is fundamental. (PATEMANN, 1970; SINTOMER in BACQUE, SINTOMER, 2011).
} 
From Dahl, despite all differences surrounding the debates on democracy, it is possible to find a certain unity in the conclusion that is sought with as much equality and freedom as possible, the will of the citizens in decisions that impact on life in society ${ }^{3}$. In representative democracies, these choices define less the decisions and more the decision-makers.

The legitimacy of decisions by equality and freedom of choice is the factor conveyed in democratic theories ${ }^{4}$. Freedom and equality ensure that the strength of the majority does not become an autonomous element that ends up oppressing minorities ${ }^{5}$.

In this perspective, the way in which the will is formed becomes a key element in the quality of democracy.

\section{INFORMATION AND THE CENTRAL ELEMENT OF DEMOCRATIC WILL: FAKE NEWS AS A FACTOR WITHIN THE CONTENT CONTROL}

The will of a citizen is formed by a complexity of factors (ALLCOTT; GENTZKOW, 2017; RAIS, et al, 2018; FIGUEIREDO, 2008) that are not always rational. As it is so in private life, it would not be different when it finds its democratic

\footnotetext{
${ }^{3}$ Even for the defenders of the lottery as a democratic instrument par excellence there is concern about the representative sample. For all, Yves Sintomer explains as a third thesis of his work "The power of the people: citizens' juries, lottery and participatory democracy" that "referring to the meaning of the current return of the lottery in politics, also seems to be subject to a response and centered on the notion representative sample. Random selection, as it now appears in politics, is inseparable from this concept. It makes it possible to constitute a "minipublic" and a counterfactual public opinion that differs from the public opinion of elected politicians, but also from the public opinion in general. This is clearly perceptible in the way James Fishkin, the inventor of deliberative research, presents the logic of this mechanism. In this way, the reference to Athens, based on the draw and the face-to-face discussion, seems more problematic than initially " (2010. p. 183).

${ }^{4}$ This does not exclude criticism, such as that of Yves Sintomer in the sense that "the election embodies an aristocratic principle" while "the lottery is a democratic instrument par excellence" (2010, p. 181).

${ }^{5}$ For Hans Kelsen, "if one tries to derive the principle of majority only from the idea of equality, it would inevitably have that mechanical and absurd character which the autocracy's supporters reproach him for. It would be only the poorly formalized expression of the experience that the many are stronger than the few, and the proposition 'the raw force over the Law' could only be overcome by making itself a legal proposition. " In the face of the controversy he proposes that "only the idea that they should be free, if not all, should at least as many men as possible - that is, that as few men as possible should be in the situation that their will is in contradiction with the general will of the social order - leads in a reasonable way to the majority principle" (2009. p. 51-52).
} 
role. When it comes to the freedom of vote, the question is whether misinformation is capable of impacting on the autonomy of the will.

It is not questioned which affective and emotional factors are relevant in the formation of choices, especially when inserted in the electoral process ${ }^{6}$. What is investigated in this study, however, does not contrast with this assumption: it seeks to evaluate to what extent information is also relevant and how misinformation acts in the formation of the wil.

In fact, the recognition that the will is formed by a rational and emotional process is complementary in this investigation. After all, an ocassional misinformation network may serve as a tool to foster the deepening of emotions that may interfere, maliciously and orchestratedly, in the formation of the will.

As Diogo Rais (2018, in press) points out, this concern is not new and was the subject of debates in the nineteenth century when "the cheapening of paper and the technological advancement of printing presses allowed partisan newspapers to expand their reach" (ALLCOTT; GENTZKOW, 2017, p. 16) and, in the twentieth century, when radio and TV dominated the communication process, there was a risk whether "favoring a kind of manipulation of the electorate in the behalf of media-fostered candidates, instead of candidates best fit for office, would end up choosing the most televised ones "(Alcott, Gentzkow, 2017, p.16).

In traditional media, the impact of the media on the formation of voters' will is recognized as a factor of relevant interference in the freedom of vote ${ }^{7}$. For no other reason, the Brazilian legal system described the abusive use of the media as an unlawful act capable of corrupting the legitimacy of the polls. Although the focus was not on misinformation, a conviction for the practice of such an offense leads to the annulment of the registration, diploma or term of the beneficiary or liable person (article

\footnotetext{
6 In this direction, Jónatas Machado $(2002,242)$ states that "traditional Cartesian epistemology, structured around ideas of rationality, objectivity, neutrality and universality, has undergone a procedure of critical deconstruction and complemented, if not substituted, by perspectives open to the ideas of emotion, subjectivity, commitment and contextuality"

${ }^{7}$ A recent survey by the Reuters Institute (commissioned by Oxford University) placed Brazil in second place in the world's public confidence index in relation to the media. No less than $60 \%$ of the respondents said they trust the media content, which is only surpassed by Finland. Available in: <http://www.digitalnewsreport.org/>. Acesso em 25 fev. 2018.
} 
22 of LC 64/90). Why would it be different in the new media that have much more sophisticated and complex tools for reaching specific groups?

Whatever the means of communication, information is presented through language (spoken, written or in image). The format in which it is presented stems from the strength with which the information impacts on the recipient. The power of traditional media was not only in the oligopoly of the platform and content producers [what has become diffused with technology], but in the ability to shape words, images, and symbols ${ }^{8}$. In the ability to present the facts from its point of view, coincidental or not with most or even with the actor who sees his or her story told.

The narrator seeks to convince his recipient. Misinformation, especially when maliciously produced, does not escape the even deeper goal of convincing its recipients of the content it conveys. The pretense of convincing the recipient involves the most diverse strategies, including projecting an image of power and influence of those who produce the content.

The practice is not new even in everyday life, but it has been sophisticated in the new communication platforms. In a bid to restore the reliability of the platform, Twitter announced in July 2018 that it will begin removing tens of millions of suspicious accounts. The overhaul seeks to reduce the widespread form of fraud by which many users incite their followers with automated or fake accounts, floating the ideia of social influence to reinforce their political activism, business ventures, or entertainment careers (Confessore, Dance, 2018)

It seems clear that the new technologies add momentum to the scenario of misinformation which is produced by players everywhere who, with tools of low cost and easy access, manipulate images with great fidelity; establish interest groups and reach the universe of the user's preferences; they disseminate false or manipulated information anonymously with the use of robots. All this intencifies the inability of the information recipient to dialogue with its content (CONFESSORE; DANCE, 2018).

\footnotetext{
${ }^{8}$ Edurne Uriarte (2010, p. 50, apud ALVIM, 2018) ratifies the position, adding that the element that characterizes ideological power is the possession of knowledge or, above all, the ability to manipulate words, concepts and symbols, re-signifying them luck to shape them to a particular interest. The Spanish scientist points out that if ideological power manifests primarily through the word, journalists exercise great control over it, since most intellectuals operate primarily through the means of communication.
} 
Likewise, Facebook has initiated a more aggressive policy of combating "coordinated networks that are hidden by the use of fake accounts, hiding from people the naure and source of their content with the intent of generating division and spreading misinformation. ${ }^{9}$ This model of strengthening credibility involves a kind of information laundering ${ }^{10}$ seeking to circumvent the Facebook algorithm.

As if that weren't enough, in this digital age, the concerns are even more diffuse. The so-called "echo chambers" or "digital bubbles" are a relevant factor that would isolate groups little permeable to the debate and eager for the reaffirmation of their points of view, which would benefit from the ocean of available information. It is also noteworthy the power of social media - once typical of radio and TV - on platforms that turn any user into a content producer without any significant filtering and with audience reach exceeding traditional media means of communication.

Considering the relevant universe of citizens accessing the internet in Brazil ${ }^{11}$ and the interaction of users with each other and with the content itself - way broader than in traditional media - it seems difficult, if not impossible, to argue that this universe of information has no potential to impact on the formation of the will of the citizen in general and, above all, the voter who goes through an extremely short and regulated electoral process in Brazil.

\footnotetext{
9 About this: "Facebook retira rede de páginas e perfis do ar e atinge MBL". Avaiable in: <https://www1.folha.uol.com.br/poder/2018/07/facebook-retira-rede-de-paginas-e-perfis-do-ar-eatinge-mbl.shtml>. Acesso em 20 jul. 2018. "Working to stop misinformation." Disponível em: <https://www.facebook.com/facebookmedia/blog/working-to-stop-misinformation-and-false-news >. Access 20 jul 2018.

10 How it works? Little tanned news [which amounts to saying little certified] only appear organically at a low percentage of the friends of the public. The more tanned the publication has - because it also favors Facebook's commercial interests for ad sales - plus the percentage of organic exposure in the news feed increases. This is because the algorithm understands that it is a certified and therefore reliable information. Aware of this, certain users create fake accounts and form a network of friendship. In this network, all publications are tanned by $100 \%$ of the friends, which promotes a confidence wash in the reading of the algorithm. This increases the organic reach of the publication, the potential for sharing by other users, and possible impetus through professional pages that take care only of "replicating" the news. "Alcance orgânico do Facebook: suas dúvidas respondidas. Disponível em: $<$ https://pt-br.facebook.com/business/news/BR-Alcance-organico-no-Facebook-suas-duvidasrespondidas >. Acesso em 05 jul 2018.

${ }^{11}$ It is estimated that there are about 139 million users, among whom $90 \%$ use the Internet daily. Half of the Brazilian population accesses the Internet through mobile devices and remains connected, on average, 8:56 a day, with 3h43 in social networks. 122 million are active users of social media. "Digital in 2017 Global Overview". Available in: <https://www.slideshare.net/wearesocialsg/digital-in-2017global-overview>. Acesso em: 30 jul. 2018:
} 
The force of the impact caused by misinformation published in the new (social) networks led Siri Lanka to temporarily suspend Facebook. Posts falsely stating that Muslims in Sri Lanka were poisoning the food given to Buddhists were removed after an investigation of the very plataform, but nevertheless led to various attacks and deaths of Muslims ${ }^{12}$

That is why it is so important the debate of how this interference occurs and how to react to the instances when it is damaging. After all, just as access to information ensures greater autonomy, misinformation is able to reduce the degree of equality among users of these platforms and the freedom with which the will is formed.

This is the extent to which misinformation becomes a major problem in democracy. As in the democratic regime, it is essential to ensure that the will of the citizen is formed with the greatest degree of equality and freedom, democratic legitimacy depends on the free expression of will.

\section{THE SIX DIMENSIONS OF MISINFORMATION AND A SNAPSHOT OF THE CONTENT CONTROL}

As we have seen, the discussion about the impact of misinformation on democratic regimes traces back a long way. There has always been such content production (by the press, by the scientific community, by companies and by citizens individually), but its large-scale dissemination was subordinated to oligopolized communication platforms.

Back then, there were no shortages of debates about the limits imposed on content control: the criminalization of lying in electoral campaigns ${ }^{13}$, restrictions on freedom of expression in the electoral and pre-electoral period ${ }^{14}$, the definition and prohibition of hate speech, the prohibition of disclosing information in certain time and

12 "Sri Lanka blocks social media as deadly violence continues". Disponível em: $<$ https://www.theguardian.com/world/2018/mar/07/sri-lanka-blocks-social-media-as-deadly-violencecontinues-buddhist-temple-anti-muslim-riots-kandy>. Acesso em 22 jul. 2018.

${ }^{13}$ Art. 323, Lei 4.737/65 (Electoral Code).

${ }^{14}$ Art. 36 and ss. and art. 36-A da Lei 9.504/97 
form ${ }^{15}$, the impact of Photoshop on the understanding of reality, truncation and montage to produce humor about characters of political life etc ${ }^{16}$.

The study of the theme, however, gained another dimension in the face of new technologies. The modification of the scenario of dissemination and access to information brought the discussion to another level. We are faced with the creation of new communication platforms (Twitter, Facebook, Instagram, YouTube etc), the expansion of technologies that allow us to conceal the truth with perfection (for example the Deep Fake News), the proliferation of content producers (any individual creates profiles and publishes content freely), the perpetuation of information (which can be retrieved by any individual or re-circulated at any time), the creation of new content-driven forces (bots, individuals with millions of followers, organic sharing).

At this point, the study seems to propose a first challenge: to systematize the points of analysis and where the intent of control of what is conventionally called Fake News, but is rather referred to as misinformation ${ }^{17}$.

It seems that the impact of information on the citizen's will does not only have one dimension. Considering the elements that have the potential to reduce the freedom of the voter, impacting on his or her autonomy of will by means of (mis) informative content, we proposed to segment the theme into six (6) elements: i) the sender of the (mis) information; ii) the person responsible for the production of (mis) informative content; iii) the (mis) informative content itself; iv) the platform or means by which the (mis) informative content is made available; v) the moment in which the (mis) information is made available; and vi) the receiver of the (mis) informative content.

\footnotetext{
15 Idem.

${ }^{16}$ This discussion can be verified, for example, in the Federal Supreme Court's judgment of ADI 4451. Available <http://www.stf.jus.br/portal/jurisprudencia/listarJurisprudencia.asp?s1=\%284451\%2ENUME\%2E+OU +4451\%2EACMS\%2E\%29\&base=baseAcordaos\&url=http://tinyurl.com/hpebxtb>. Acesso em 17 ago. 2018.

17 As Diogo Rais warns (2018, in press) "The polysemy applied to the expression fake news further confuses its meaning and scope, sometimes indicating as if it were false news, sometimes as if it were fraudulent news, or as if it were a report deficient or partial or even an aggression towards someone or to some ideology ... The great difficulty in conceptualizing fake news to meet all expectations was one of the reasons why the High Level Group - HLEG (High Level Independent Group on false news and online disinformation) of the European Union has recommended that the term Fake News be abandoned because it has been 'misused and misused by powerful participants to disregard reports that are not in their best interests"'
} 
Each requires specific analysis and could be the subject of a research of its own. As discussed earlier, this study is devoted to the item related to the content of information (iii), specifically to cases in which the disseminated content is misinformation and may impact on the electoral process. It is at this point that the debate on the control of so-called Fake News in the elections lies.

\section{THE ELECTORAL PROCESS AS A SPECIFIC AREA OF CHOICE: THE TREATMENT OF THE ISSUE BY THE ELECTORAL PROCESS CONTROL BODIES AND THE CHALLENGE OF BALANCING FREEDOM AND CONTROL}

The first question that arises from what has been seen is whether the control of informational content deserves differential treatment during elections.

As seen, the debate about the dissemination of misinformation comprises a universe of old discussions about content control renewed by the creation of technologies that modified the information issuers, the content producers, the quality of the information, the platforms of diffusion and the time of court hearing.

It is undeniable that this new scenario defies daily life, but presents itself even more challenging in the electoral process. Difficulties are compounded in Brazil not only by the short-term electoral process - which challenges candidates and their supporters to reach the voter with their information - but also by the extensive regulation ${ }^{18}$ that limits the disclosure of content, making the task even more difficult to ensure that the voter knows the candidates, the parties and their platforms.

The debate on the intent to differentiate the content control regime in the electoral process is, therefore, reaffirmed - as, incidentally, it is already characteristic

\footnotetext{
${ }^{18}$ There are innumerable limitations of content and form, which would require a study of its own. But as an illustration, the rule that defines not only the dimensions, but the material and the place of placement of electoral propaganda, in private property, during the electoral process is valid.

Art. 37 da Lei 9.504/97 [Writing provided by Law no 13.488, de 2017]:

$\S 2^{\circ}$ The broadcasting of electoral propaganda material in public or private property, except for:

I - flags along public roads, provided that they are mobile and do not impede the smooth movement of people and vehicles;

II - plastic adhesives on automobiles, trucks, bicycles, motorcycles and residential windows, provided they do not exceed $0.5 \mathrm{~m}^{2}$ (half a square meter).
} 
of the Brazilian electoral system. It is then necessary to evaluate how the Electoral Justice - body that controls the information that reaches the electoral process - has been addressing the matter.

This analysis will allow us to face the fact that although some debates about control of information content are old, it is necessary to assess whether the technological changes that bring greater capacity to weaken the freedom of voting do not require some institutes to be rethought.

The regulation of parties, candidates and voters' activities to guarantee freedom of voting, has a broad spectrum which can be summarized as follows: i) reduction of the influence of economic power in elections (prohibition of abuse of economic power, vote buying, unlawful campaign spending and fund raising); ii) reduction of the use of political power as a factor of influence in the will of the voter (prohibition of the abuse of political power and unlawful bahavior); iii) barring the media from being misused so as not to interfere with the will of the voter (banning of corruption and fraud).

Thenceforth, the major concern of the legislation was with the manipulation of information by the holders of mass media means. Nevertheless, there was no relevant concern with a general duty to combat misinformation:

\footnotetext{
"Mass journalism, which reaches and is capable of mobilizing or demobilizing people, is currently under the control of few people. It is remarkable the influence of television and of so few people in the country. In Brazil, it is striking the clout of television and of the press in the choice of presidents and in the construction and destruction of idols. The fact is that today we live in a society in which between the reality and the individual lies the media, especially, television "(MAGALHÃES, 1999, pp. 88-89).
}

The regulation of this sector and the protection of freedom of the press and of freedom of expression was meant to guarantee the pluralism of diverse sources so that citizens were not easily manipulated by a single point of view. Freedom of expression and freedom of the press have fulfilled - and they play a very important role in this scenario.

In this context, we sought to understand how the Superior Electoral had faced, until then, the question of misinformation. Taking into account the 2018 general elections, the research aimed at the period prior to the electoral process. The 
information presented addressed rulings up to August 7, 2018. The research does not reach decisions made within the 2018 election which had not yet been fully concluded and deserve further analysis.

Survey on the websites of the Superior Electoral Court (TSE) and of the Regional Electoral Courts (TREs) of the 27 (twenty-seven) states of Brazil confirms this conclusion. After conducting a search with the term "desinforma $\$ 19$ (misinformation) in the TSE case-law ${ }^{20}$ and at 27 (twenty-seven) TREs only six (6) results were yielded: 1 (one) TRE-AC decision ${ }^{21}, 1$ (one) TRE-AM decision ${ }^{22}, 1$ (one)

\footnotetext{
${ }^{19}$ The \$ operator in the jurisprudential search replaces any part of the desired word, ie, prefix, radical, or suffix. Therefore, research with the expression disinformation $\$$ would return any of the words misinform, uninformed, disinformation, misinformation, etc.

${ }^{20} \mathrm{http}: / /$ www.tse.jus.br/jurisprudencia/decisoes/jurisprudencia

21 TRE-AC, RE 18, Acórdão 16/2000, Rel. David Pardo, DOE 10.8.2000: 1. The transmission by television station, in the form of a journalistic interview, of a program in which the interviewees are candidates for mayor and deputy mayor is prohibited, especially when privileged treatment is characterized to said candidates (article 45, subsections I and IV of Law 9,504 / 97). It is only allowed to hold debates on the majority elections, with the participation of all the candidates in the same elective position, or in groups of at least three candidates (article 46, paragraph I, items a and b, of Law 9.504 / 97). [...] 5. In addition, freedom of journalistic information corresponds to the right of citizens to have access to the right information. Those who use media to gain political-electoral advantage, misinforming, issuing contrary opinion to candidate and giving privileged treatment to others, is not exercising the freedom of journalistic information, as it is not informing correctly. The Federal Constitution does not protect the exercise of the freedom of aggression, deformation, disinformation, conduct that must be repressed, for the legitimacy (equality) and normality (smoothness) of the electoral process. 6. Configuration of irregular electoral propaganda, in its positive and negative forms, justifying the application of a fine by the Electoral Judge. [...]

22 TRE-AM, PA 492000, Acórdão 134/2000, Rel. Divaldo Martins da Costa, DOE 8.8.2000: does not relate to the content control theme. It deals with "the conduct of the applicant, if it infers only disinformation regarding the electoral rules concerning electoral domicile and application for registration of candidate, dispatches the consignment of pieces to the First Electoral Public Prosecutor, for the purposes of art. 40 of the CPP."
} 
TRE-MS decision ${ }^{23}$, one (1) TRE-RJ decision ${ }^{24}$, one (1) TRE-RS decision ${ }^{25}$ and one (1) TRE-SC decision ${ }^{26}$.

The survey revealed that there was no debate ${ }^{27}$ at the Superior Electoral Court regarding the issue of misinformation. In the regional courts, only two (2) referred to the misinformation in the context of content control. One of them (TRE-RJ) analyzes the perspective of the abuse of economic power and the other (TRE-AC) considers irregular advertisement interview broadcast by a medium favoring a candidate because it would contain aggression, deformation, misinformation.

The result of search in unilateral decisions of the Superior Electoral Court is no different. The search for the same expression " desinforma\$" on TSE's own link 28 yielded only two (2) ${ }^{29}$ results that were not related to content control.

\footnotetext{
23 TRE-MS, RE 116, Acórdão 3782/2000, Rel. Julizar Trindade, DJ 19.12.2000: does not relate to the content control theme. It deals with non-communication (misinformation) about the condition of a public good occupied by private individuals.

24 TRE-RJ, RE 7330, Acórdão 52.232/2010, Rel. Leonardo Antonelli, DJERJ 1.10.2010: "Electoral recourse. Action to challenge an elective term. Abuse of economic power. Illegal capture of suffrage. 1 - The sentence is not null and void, which is duly substantiated and covers all the necessary points to substantiate the conviction of the judge. 2 - Maintenance of social centers in needy areas that constitutes abuse of economic power, due to the undeniable imbalance of the electoral process in favor of the candidate who appears as benefactor in the eyes of the needy and uninformed voter. 3 - Illegal capture of suffrage typified by the evidence in the records of requirement to fill application support forms as a requirement to use the services offered by the social center. 4 - Documentary and oral evidence that are sufficiently robust to support a condemnatory decree. 5 - Welfare practice in exchange of votes that compromises the salubrity of the institutions supporting the Democratic State of Law, thus deserving the repudiation of the Judiciary. Appeal dismissed."

25 TRE-RS, RE 133, Acórdão 10.5.2012, Rel. Maria Lúcia Luz Leiria, DEJERS 16.5.2012: does not relate to the content control theme. It deals with "reality of the small municipalities that suffer with disinformation and unprepared of the municipal organs of the parties."

26 TRE-SC, AGREG 3157, Acórdão 29365/2014, Rel. Bárbara Thomaselli: "INEXISTANCE OF THE CHARACTERIZING ELEMENTS OF ANTICIPATED ELECTORAL PROPAGANDA - DUTY OF PUBLICITY OF ART. 37, § 1, OF THE FEDERAL CONSTITUTION, WHICH IS NOT CONFUSED WITH EXTERNAL ELECTION PROPAGANDA - IMPAIRMENT OF REPRESENTATION. [Precedentes TRES. Ac. n. 28.155, de 24.4.2013, Rel. Juiz Luiz Antônio Zanini Fornerolli; Ac. 28.440, de 7.8.2013, Rel. Juiz Luiz Henrique Martins Portelinha; Ac. n. 28.524, de 26.8.2013, Rel. Juiz Ivorí Luis da Silva Scheffer; Ac. n. 27.764, de 25.10.2012, Rel. Designado Juiz Marcelo Ramos Peregrino Ferreira; Ac. n. 27.802, de 8.11.2012, Rel. Juiz Nelson Maia Peixoto; Ac. n. 27.803, de 8.11.2012, Rel.Juiz Nelson Maia Peixoto]." The term disinformation appears only in the defeated vote: "Lying advertisements, ostensibly false like these, are not educational, socially oriented or informative, repeating the almost naive terms of the Constitution. The purpose is unique. We want to spread, even subliminally, the message of a responsible, efficient and efficient government. You want electoral advantages. Advertising misleads, disinform and discourages."

${ }^{27}$ Até a data de acesso: 30 jul. 2018.

${ }^{28} \mathrm{http}: / /$ www.tse.jus.br/jurisprudencia/decisoes/monocraticas-do-tse

29 TSE, Al 1706491, Rel. Min. Arnaldo Versiani, DJe 11.06.2012- no 108 -p . 44-52; e TSE, Respe 3934297, Rel. Min. Arnaldo Versiani, DJe 04.08.2010, p. 120-131.
} 
In turn, when searching for decisions with the entry Fake News on the TSE jurisprudential search link ${ }^{30}$ and on the 27 (twenty seven) TREs', there was only a single result. A recent TRE-RJ ruling mentions collaterally and en passant the expression to highlight its importance in the current contex $t^{31}$. As per the search of unilateral decisions, the same expression yields six (6) results: all in 2018, analyzing applications for preliminary injuctions ${ }^{32}$, but there was only one ${ }^{33}$ taking care of content

${ }^{30}$ http://www.tse.jus.br/jurisprudencia/decisoes/jurisprudencia

31 TRE-RJ, ED-RE 170594, Acórdão 21.2.2018, Rel. Antonio Duarte, DJERJ 26.2.2018: "As regards the use of journalistic material in the judgment and the difference between public fact and published fact, this issue is, in fact, very important in the current electoral context in which the so-called" fake news "are propagated. However, Pedro Paulo's pre-application to the City Hall, at the time of hiring the consultant to prepare the Strategic Plan, was, at the time, a public and notorious fact, and reference was made in the judgment to a report published by the Revista Time in order to better demonstrate such an issue." 321 e 2) TSE, Rp 060007991, Rel. Min. Sergio Silveira Banhos, DJe 06.02.2018 e TSE, ED na Rp 060007991, Rel. Min. Sergio Silveira Banhos, DJe 02.03.18; 3 e 4) TSE, Rp 060008161, Rel. Min. Carlos Bastide Horbach, DJe 15.02.2018 "Representation - the representative's claim that those represented be required to include in their opinion polls the name of Levy Fidelix as a candidate in the election for President of the Republic." Representative alleged that "spreading inaccurate news also called 'FAKE NEWS' as they do not properly inform the public all the options they will have to choose in the upcoming elections" (ID. 189220)"; TSE, ED na Rp 060008161, Rel. Min. Carlos Bastide Horbach, DJe 06.03.2018; 5) TSE, Al 170594, Rel. Min. Jorge Mussi, DJe 14.05.2018. The decision only mentions the term fake news collaterally when citing the regional menu. The Rel. Min. Jorge Mussi granted a provisional injunction, but the decision does not refer to the subject of control of information content, but refers to the following: "It is extracted from the factual frame of the TRE / RJ edges that the condemnation of the aggravating parties - by a tight majority of four votes to three - was solely due to the fact that Pedro Paulo attached to his application for registration of candidacy in the 2016 Election government plan that had as pillars aspects contained in the strategic plan "Vision Rio 500", launched under the management of Eduardo Paes in front of the City Hall of Rio de Janeiro / RJ."

33 TSE, RP 060054670, Rel. Min. Sérgio Banhos, DJe 08.06.2018: "There is an inescapable commitment on the agenda of the contemporary world: to ensure that the electoral process takes place on a regular basis, observing the constitutional balances, so that effectively legitimate candidates are those chosen in the 2018 elections. This is even more important in times of today, when social media has multiplied the speed of communication. Any information without foundation can be disastrous. The use of the Internet as a weapon of manipulation of the electoral process gives instead to the unlimited use of fake news calls. The practice of fake news is not recent. It is the old electoral strategy of those who make politics. As the reception of content by humans is selective and disinformation reverberates more than the truth, the use of fake news is an ancient and effective mechanism for raising the reach of information and, as a consequence, weakening applications. The significant difference in the contemporary world is that, with social networks, the spread of this malicious information became faster, easier, cheaper and exponential. It is the epoch of Post Truth - a word chosen as the word of the year 2016 by the Oxford Dictionary - in which, according to the journalist Matthew D'Ancona (D'ANCONA, Matthew, Post Truth - the new war on truth and how to Ebury Press, 2017), author of the Post-Truth book, "Certainty prevails over facts, visceral over rational, deceptively simple over honestly complex." Our time undoubtedly prefers "the image to the thing, the copy to the original, the representation to reality. Anyway: the appearance to be ". This is because the deepest human truth is emotional, subjective and dispenses with the facts. Distorted news with a strong ideological bias, brought by social media, more often than not, receive more attention than the reports made by the traditional press. False, tabloid material tends to be easily passed on, to become more virulent, to become trend topics faster than those produced by zealous journalists practicing the facts. It is the force of lies overcoming the real events, which stimulate excessive political polarization, generating fertile ground for voter misinformation. We live in liquid times. According to the Polish philosopher Zygmunt Bauman (BAUMAN, 
control of disclosed information. In this case, the Rapporteur judge notes that "any unfounded information can be disastrous. The use of the Internet as a weapon of manipulation of the electoral process allows the unlimited use of the so-called fake news. The practice of fake news is not recent. It is an old electoral strategy for those who make politics." And he points out that, in this case, the posting profile had more than 1.7 million followers, which strengthens the Fake News' viralization.

Zygmunt, Liquid Times, São Paulo: Zahar Editora, 2007), our world is full of uncertainties: everything around us is precarious; everything becomes more and more rapid. Our reality is therefore liquid. Nothing is meant to last, to be solid. It is a world of uncertainties. And all this, all this reality, tends to generate the manipulation of the political debate in social networks. The high price of campaigns on the streets, in an election that will be marked by the limitation of financial resources due to the prohibition of donation by legal entities, will bring a situation never before faced. These are times of transition, which impose us double caution. In this new trajectory, we must have as allies the ancient weapons of humanity: common sense, the notion of ethics, respect for others, fraternity and prestige to the rules of the game. The 2018 elections have the potential to represent a turning point in our democracy. That is why it must be a commitment of all the actors involved to promote the regular course of the electoral process, a necessary and indispensable condition for the legitimacy of the elect. We must be willing and engaged in making these elections a fair dispute, with unconditional respect for the rules of the electoral contest, demonstrating loyalty to the institutions and the democratic regime. In this area, the intervention of the Electoral Justice, even by the importance of social media in these elections of 2018, must be firm, but surgical. It is to know how to establish the counterpoint between the right to freedom of expression enshrined in the Federal Constitution of 1988 and the right also constitutional and sacred to exercise active citizenship, in order to guarantee everyone the right to vote consciously, from conceptions based on the truth of the facts, seeking the adhesion of the electoral result to the real will of the voters. It is about citizenship and legitimacy that this is about.

The "Anti-PT Party" profile often posts inflammatory and sensationalist news, often political in content, often containing data of questionable veracity or unverified information. In the present case, the representatives denounce the existence of several publications containing untruthful information about the pre-candidate Marina Silva. The headlines, exaggerated and effusive, state that the representative is "negligent and opportunistic, negligent and conniving" with corruption and associate it with Operation Lava jet and receiving tip. The aforementioned criticisms and news were published anonymously, that is, both the publications and the links contained therein do not indicate the authors of the texts. The Facebook profile, in its statement of authorship, states that it is "a page dedicated to the more than 84 million Brazilians who are against this corrupt, lying and incompetent government ...". Although freedom of expression constitutes a fundamental guarantee of constitutional stature, its protection does not extend to anonymous manifestation (article 5, section IV, of the CF). The absence of identification of news authors, therefore, indicates the need to remove publications from the public profile. Even if this were not the case, I note that the information is unproven and merely states facts that are devoid of source or reference, for the sole purpose of creating a commotion about the person of the pre-candidate. In fact, the stylistic conformation of the posts can also indicate, indicirally, the existence of false content. Although it can not be said that all fake news are written in the same way, recent research already indicates the existence of a relatively common pattern in this type of publication, even identifiable by artificial intelligence. Common traits include the sensationalist headline, the prevalence of the first person in the text, errors in grammar and cohesion, and the use of words of judgment and extremism (https://medium.com/data-science-brigade/a -Activity-of-detection-of-fake-news-d4faef2281aa. Access on 6.6.2018). Moreover, it is undeniable that such postings could lead to serious losses in the particular case. The "Anti-PT Party" profile has more than 1.7 million followers, which strengthens the aforementioned viralization of fake news. Therefore, considering the precautionary assumptions, I understand that it must be granted to the injunction in order for the proxy to remove the URLs indicated by the representatives within 48 hours, pursuant to art. 33, § 3, of Res.-TSE no 23.551 / 2017." 
The granting of this preliminary injuction was widely reported ${ }^{34}$ as the first decision of the Superior Electoral Court in the fight against Fake News. So far, it seems to have been the first and only one.

In fact, the protection of the citizen against misinformation - or the guarantee that he or she is able to dialogue with false content was not the object of the electoral justice. Until then, this duty to combat misinformation - and the benefit derived from information asymmetry - was thought of as a result of the state's role of providing general information and formal education.

The protection of the candidate [and indirectly of the voter] against false information during the electoral period has always been subject to more specific protection only in the right of reply. Currently, art. 58 of Law 9,504/97 provides that "from the choice of candidates in convention it is guaranteed the right of reply to a candidate, party or coalition affected, albeit indirectly, by concept, image or affirmation that is slanderous, defamatory, libelous or knowingly untrue, broadcast by any means of social media." To this end, it is considered a knowngly untrue fact the one that does not demand investigation, outright ${ }^{35}$.

There are also criminal provisions that criminalize the disclosure of untruthful facts in electoral propaganda (article 323 of the Electoral Code); slander, libel and defamation in electoral propaganda (Articles 324, 325 and 326 of the Electoral Code); the turning into no use, alteration or disruption of lawful electoral propaganda (article 331 of the Electoral Code); impeding the exercise of electoral propaganda (article 332 of the Electoral Code); use of symbols, phrases or images of public entities in electoral

\footnotetext{
${ }^{34}$ As an example, the following reports are quoted: "In favor of Marina, TSE, takes 1st decision against 'fake news' in the election." Economic value. Available in: <https://www.valor.com.br/politica/5580559/em-favor-de-marina-tse-toma-1-decisao-contra-fakenews-na-eleicao>. Access 16.08.2018. "TSE applies for the first time standard that curb news fouls on the internet." Press Office Superior Electoral Court. Available in:

$<$ http://www.tse.jus.br/imprensa/noticias-tse/2018/Junho/tse-aplica-pela-primeira-vez-norma-quecoibe-noticias-falsas-na-internet>. Accessed on 08.18.2018; "For the first time, TSE sends fake News off the internet." Brazilian Agency. Available in:

<http://agenciabrasil.ebc.com.br/justica/noticia/2018-06/pela-primeira-vez-tse-manda-retirar-fakenews-da-internet>. Accessed on 08.18.2018; "For the first time, TSE determines fake news exclusion against presidential." Jota. Available in:

<https://www.jota.info/eleicoes-2018/tse-determina-exclusao-fake-news-marina-silva-07062018>. Acesso em 16.08.2018.

35 This understanding was adopted by the Superior Electoral Court in the following precedents: TSE, Rp no 139448, Acórdão, Rel. Min. Admar Gonzaga Neto, Publicado em sessão em 02.10.2014 e, TSE, Rp no 120133, Acórdão, Rel. Min. Tarcisio Vieira de Carvalho Neto, Publicado em sessão em 23.09.2014.
} 
propaganda (article 40 of Law 9,504 / 1997); fraudulent search (Article 33, §4, of Law $9,504 / 1997)^{36}$.

This theme gained strength in the 2018 elections, after questionings related to Brexit and the US and French elections.

It took some time to realize that rules designed for a world of communication that worked from one to one/few or from an oligopoly to many do not work in the diffused communication from anyone to many. Especially when this "anyone" is random and can be boosted with technological and financial resources.

It may be that in the future, with the deepening of the internet of things, individuals will access and absorb all knowledge in a uniform and equitable way. However, until a disruptive innovation promotes such a change, one does not even consider a utopian ideal in which voters are not affected by the effects of information asymmetry. It is precisely using the asymmetry between what the voter knows and what content producer disseminates that the effects of misinformation germinate, reducing the degree of freedom that governs the decision to be made at the time of voting.

For all the above, a possible partial conclusion is that the electoral process, inserted in a democracy as an instrument of egalitarian and free will manifestation, must have specific treatment in the fight against misinformation. The participation of citizens through the manifestation of will in a democratic rule-of-law state is a constant element and materializes in the most diverse forms ${ }^{37}$. However, in the modern democracies (BOBBIO, 2000, p. 371), the act of voting is not only relevant and punctual, it is not usually practiced to decide, but to elect who should decide for long years.

It means to say that misinformation, as an influence capable of impacting on the autonomy of the will leading to the selection of leaders for a relatively long period, must be addresed more rigorously than in daily life. As a decision-making tool, the degree of freedom of voting greatly defines, to a large extent, the quality of democracy.

\footnotetext{
${ }^{36}$ These crimes were the object of Fernando Gaspar Neisser's dissertation (2016).

37 Examples include popular initiative in bills, public hearings and consultations, parity in executive bodies, oversight and in the judiciary itself, participatory budgeting, petition rights and public ombudsmen.
} 
These premises ultimately lead us to the following questions: what kind of Regulatory interference the claim to guarantee the freedom of voting, considering the relevance of this decision, concentrated in time, which is dated and whose effects extend for years would justify? Does the current model account for the technological disruption and interference in the voter's manifestation of will?

\section{IS THERE A DUTY TO COMBAT MISINFORMATION AND WHO WOULD BE ITS RECIPIENT OR THE JUDGE OF TRUTH?}

Based on the consideration that misinformation causes significant restrictions on voters' freedom of voting and interferes with the autonomy of their will, it seems clear that in a regime that is intended to be democratic, there is a general duty to combat misinformation. The question that arises immediately is how to instrumentalize it.

This instrumentalization must consider, as already stated, that the very regulation of the electoral process still favors misinformation. As Aline Osório (2017, p. 43) points out, "the contempt for the freedom of expression in Brazil has a very problematic face. It manifests itself, above all, when the free circulation of information and opinions is more important: in the elections."

The counterpoint does not resist a systemic analysis of the rules that - aiming at restricting abuse, especially economic power - end up limiting voter access to the electoral process and its actors, to the ideological content of the campaign and the candidates as well as a frank open and in-depth dialogue with themes that should guide the decision-making process.

In view of the relevance of this point, some of the issues are reaffirmed: restriction of advertising before August 15 of the election year (article 36 of Law $9,504 / 97$ ) 38 as opposed to overexposure of current and former rulers (underscored by

\footnotetext{
${ }^{38}$ Although enlivened by new positioning formed in AgRg 9-24 / SP and REspe 43-46 / BA in which the TSE decided based on the previous Buckley vs.. Valeo, of the Supreme Court, that only the explicit request for votes characterizes the performance of irregular early advertisement. Order identified in socalled "magic words" (magic words): (i) vote in (vote for); (ii) elect; (iii) support; (iv) mark your ballot (cast yourballot for); (v) So-and-so for Congress (Smith for Congress); (vi) vote against; (vii) defeat (defeat); and (viii) reject. In addition, it defined that (i) voters are indifferent to personal promotion messages that
} 
constitutional authorization for reelection); extremely shortened electoral period; countless limitations of content and of form in the dissemination of electoral propaganda (in the period of the very campaign), public funding that reaches candidates filtered by party autonomy that is not based on internal democracy (art 17 of the $\mathrm{CR} / 88$ ); prohibition of financing of legal entities; Countless restrictions on fundraising and spending, even with the definition of a spending cap; re-election to the head of the executive branch for a subsequent term and without limitations to the legislative branch of power (article $14, \S 5$ of CR/88).

In the current Brazilian system, the instrumentalization of mechanisms to combat misinformation ends up, to a large extent, at the Electoral Justice. As described by Fernando Neisser (2016: 52), "voters must be given the opportunity to know everything, to know what each option represents, the benefits and losses that may arise. One should be given the power to stipulate limits to this free circulation of ideas, with the protection of the electorate against the influences considered illegitimate in the formation of its will. In Brazil, this Herculean task, is attributed to the Electoral Justice, with constitutional and legal delineations." Evidently, the Electoral Justice is subject to the rules to play this role.

We have already pointed out some norms and the position that the Electoral Justice has adopted, in general, regarding misinformation in the electoral process so far. With the emergence of the internet and, more recently, with social networks, the legislation has tried to present mechanisms of contention to the dissemination of content that it considers capable of misinformation.

That said, the electoral legislation does not fall short of rules. It guarantees the right of reply against the disclosure of facts "known to be untrue or offensive" (article 58 of Law 9,504 / 97). It typifies as a crime: "to divulge, in advertising, facts that are untrue, in relation to parties or candidates and capable of exercising influence before the electorate (article 323 of the Electoral Code) and also the "direct or indirect hiring of people with the specific purpose of sending messages or comments on the Internet to offend the honor or denigrate the image of a candidate, party or coalition" (Article

are not related to the election, and (ii) personal promotions once considered advertisements - related to the electoral process - must comply with the restrictions of form and content anticipated at the time of the elections. 
57-H, §1 of Law 9,504 / 97); crime attributable to whom is hired and not to whom hires (article 57-H, §2 of Law 9,504 / 97). It establishes a fine for those who "carry out electoral propaganda on the Internet, improperly assigning its authorship to a third party, including a candidate, party or coalition" (Article 57-H of Law 9,504 / 97) and for those who convey "electoral content through registration of internet application user with the intention of falsifying identity" (article 57-B, § 2 of Law 9,504 / 97).

Considering the recent experiences of other countries ${ }^{39}$, there is great fear that these instruments will not be sufficient to combat malicious practices that seek to misinform voters to interfere fraudulently with their freedom to vote. In view of this, some discussions have been put forward on the best ways to ensure that the quality of democracy, in terms of freedom of voting, is not reduced by the impact of misinformation and negatively affected by new technologies.

In the first moment, it is pointed out that the responsibility for the investigation of the information would be of its recipient. We point out that leaving the debate open in the broad market of ideas would be the most effective way of guaranteeing freedom and equality in the democratic state. Thus, freedom of expression, freedom of the press and scientific freedom, open to dialogue and public debate, would clarify the electorate to the extent of misinformation. It would only be necessary to enable citizens to be able to dialogue with this new universe and thus be able to critically evaluate false information or even a network of misinformation ${ }^{40} 41$.

This is the position defended by professor and researcher Diogo Rais (2018, in press) when he says that "facing the second axis of possible solutions (those aimed at empowering individuals to assess fake news) that there are better opportunities to solve the misinformation problem". It clarifies that even in the face of voluntary norms and determinations to combat an environment of misinformation "in the scenario of misinformation, the search to find the effective "remedy" to fight it must lie in the

\footnotetext{
${ }^{39}$ Especially in the French and United States elections, which discusses the potential or effective impact of the misinformation on the new media brought to the elections.

40 Soroush Vosoughi, Deb Roy and Sinan Aral (RAIS, 2018, in press) point to two categories of interventions: (i) structural changes that hinder the primary exposure of individuals to fake news, and (ii) available.

41 As for the point, see: MIT. The Spread Of True And False News Online. Available in: $<$ http://ide.mit.edu/sites/default/files/publications/2017\%20IDE\%20Research\%20Brief\%20False\%20N ews.pdf>. Acesso em: 08 mai. 2018.
} 
information." The less information we have, the more vulnerable to fake news we will be" (2018, in press).

In the same vein, is Justice Luís Roberto Barroso when pointing out in the foreward of the book Electoral law and freedom of expression, that: "as usual, freedom of expression is not a guarantee of truth or justice. It is a guarantee of democracy. To defend freedom of expression may mean having to live with injustice and even with untruth. It's the price. This should be especially true for candidates and politicians in general. Who does not like criticism, should not go into the public space. This should be especially true for candidates and politicians in general. Those who do not like criticism should not go to public space" (apud OSORIO, 2017, 21).

In this perspective of strengthening the recipient of the message, the instrument that would complement the importance of the fight against misinformation would be the data journalism made by the traditional press or by agencies of content checking or fact-checking. Every day there is an increase in the number of virtual sites that show their intent of carrying out this task, many of them are linked to means of the traditional press ${ }^{42}$.

On the other hand, there are those who argue that this duty of checking would not only be of the user's, but it should be attributed to the platforms of content distribution. One possible approach would be to classify the reliability of information. Experience in this sense, however, was tested by Facebook by placing a red-flag icon near some publications considered fake news, according to the criteria of factchecking.

However, although the method of analysis or the details of the results have not been made public, Facebook has announced that "research suggests that the "red flag" approach actually means "deeply rooted ingrained beliefs." Facebook's Tessa Lyons in a blog post said that "Academic research on correcting misinformation has shown that putting a strong image, like a red flag, next to an article may actually entrench deeply held beliefs - the opposite effect to what we intended " (BBC NEWS, 2017).That is why Facebook has decided to change the practice for the publication of

\footnotetext{
${ }^{42}$ For exemple Agência Lupa (Uol), Fato ou Fake (Seção do Valor Econômico), É ou não é (G1) and Independent Agencies Agência Pública e Aos Fatos.
} 
related articles - which dialogue with challenged content - alongside the news that would deserve the alert.

A complementary alternative would be to display a warning to the link with the news that shows the other point of view (checked) when the user intended to share the news. Facebook claims to have tested the approach and discovered that despite not having reduced the number of times the disputed articles were clicked, this led to them being shared less often (BBC NEWS, 2017).

Another path that has been debated, amidst major controversies, would be to find ways to prevent misinformation from reaching the user. The fundamental issue that assumes this initiative is the intention to deepen the judgment of the contents produced and disseminated comprehensively. And from that, to define who would be the judge of truth.

In Brazil, there are two potential actors of this initiative: the very administrators of the platform and the Judiciary branch.

On one hand, by contractual provision, displayed on its use policy, the administrators of the digital platforms as Facebook, Twitter and Instagram would have the power to judge the content published by its users and to suppress what is at odds with its terms of use. This is a practice already being carried out by some platforms and there is a lack of discussions about it.

Facebook has implemented a new policy of reviewing inaccurate or misleading posts, being created or shared with the intent to cause violence or physical harm. The platform clarifies that posts will be reviewed in partnership with local organizations, including threat intelligence agencies, which, according to Facebook, are in a better position to assess the issues. Posts covered by the policy include manipulated images as well as texts. In the face of the episode that led to the death of Muslims in Sri Lanka, Facebook stated that "there are certain forms of misinformation that have contributed to physical harm, and we are making a policy change that will allow us to remove such content" (SHABAN, online).

In April 2018, Mark Zuckerberg was heard before the Senate's Commerce and Judiciary committees and the House of Representatives Committee on Energy and Commerce. The summon derived from concerns about the company's power over how it has used and made available the data it collects, and how other actors, including the 
Russian government, take advantage of the platform's reach to achieve political goals. ${ }^{43}$ It also discusses whether the policy of suppression of content put in practice by Facebook - and intensified recently - does not constitute a violation of freedom of expression.

On the other hand, as it is characteristic of the Brazilian constitutional system, content analysis is the responsibility of the Judiciary branch. At this point, the fundamentals surrounding the guarantees of freedom of expression are even stronger. Here again, we open the debate on the possibility of exercising the Police Power assigned to electoral judges in art. 41, paragraph 2 of Law 9,504/9744. In these terms, the electoral court in the administrative sphere - without making a claim or filing a suit - could suppress propaganda content.

According to Diogo Rais, based on the assumption of contentious judicial action, "the judiciary should only enter into the matter when there is damage, or damage and deceit" (in press, 2018).

This stance takes into account that the interference of the judiciary in the content of any information limits to a greater or lesser extent the free expression of thought, freedom of expression and freedom of the press. And, in fact, it is not an easy task to balance freedom of expression with other individual rights, such as freedom of

\footnotetext{
${ }^{43}$ Reports from the American newspaper The New York Times and Britain's The Observer revealed that Cambridge Analytica, a UK-based political consultancy working in the pro-Brexit and Trump campaigns, had collected Facebook and infringed company rules on data of 87 million people, mainly Americans. Information on the irregular collection of data had already been revealed in 2015 by the British newspaper The Guardian, which owns the Observer. But the most recent reports included details: a first-hand account and documents provided by former Cambridge Analytica developer Christopher Wylie. They show that data capture took place as follows: Russian-American researcher Aleksandr Kogan, linked to the University of Cambridge in Great Britain, and St. Petersburg, Russia, obtained permission from Facebook to collect user profile data by middle of an application called "thisismydigitallife", which applied a personality quiz. To take the quiz, the participants agreed to provide both your profile information and the profiles of your friends on the network. This made it possible for a much larger number of people than those who did the quiz to be reached. In the agreement between Kogan and Facebook, the data should be used only for academic purposes. Kogan sold them, however, to Cambridge Analytica. (ROSEMBERG, 2018; HERN; CADWALLADR, 2018).

44 Lei 9.504/97, art. 41. "Advertising carried out under the terms of electoral legislation shall not be subject to a fine or to any restriction on the grounds of the exercise of police power or violation of a municipal position, in which case it shall proceed in the manner set forth in art. 40. 11 The police power over electoral propaganda shall be exercised by electoral judges and by judges appointed by the Regional Electoral Courts. Paragraph 2 Police power is restricted to the measures necessary to inhibit illegal practices, previous censorship of the content of programs to be displayed on television, radio or on the internet is prohibited."
} 
the vote, when so many atrocities arising from prejudice and racial discrimination are propagated with support on its foundation.

There are instances when misinformation will be intentionally propagated and with obvious manipulation of images or data, in hypothetical situations that do not defy the limit of freedom of expression. In many other situations, however, the debate of ideas or positions that form the so-called difficult cases will be on the agenda.

In an in-depth study on freedom of expression, Rafael Lorenzo-Fernandez Koatz (2007, p.16) concludes that "in a democratic society, consensus must be built through debate. Thus, although we do not agree with the proliferation of racist and discriminatory ideas, if democracy demands freedom of expression, then we must learn to live with these manifestations, and strive to change them and to make society accept the value of the difference". This reflection gains importance when we assess the role of the state in this task, a little further ahead.

At the other end, in the world of technology, engineers argue that "technology is fought with technology" and that this new face of combating misinformation would depend on the development of a tool capable of automating the suppression of malicious content. Just like what happened with the anti-spam system for emails. Some tools have already been developed as a web-browser plug-in that identifies whether the image of a video is real or assembled from deep fake news ${ }^{45}$.

It is worth mentioning, however, that the developers of the solution are the same creators of technology capable of leveraging misinformation. In addition, it should be remembered that this mechanism also involves the judgement of content from the perspective of defining what would be true.

Finally, it would be fitting to inquire whether the State would have a specific duty to combat misinformation beyond its jurisdictional competence and the implemented public policies of formal education. This seems to be a possible and necessary path.

This proposal is not meant to educate people in the search for a truth, arising from an actor who defines the correct news (be it the state, the digital platform or the

\footnotetext{
${ }^{45}$ Sobre o tema, veja-se: "Fake vídeos of real people - and how to spot them". Available in: <https://www.youtube.com/watch?v=02DDU4gOPRo\&feature=youtu.be>. Acesso em 17 ago. 2018.
} 
fact-checking). It requires knowledge for dialogue ${ }^{46}$ and a form of education in the news. Not just to be skeptical or find tools to question the stories told. How useful are these skills in a world where many believe that trust in institutions, including news media, is extremely low?

The dialogue with information - whether it is journalistic, scientific or personal - depends on openness to the arguments and understanding of how they are made, who does it, how the data is selected and how they are funded.

Under this duty it would be up to the state to engage in the task of promoting awareness of the importance of dialoguing with the information that is available or received. And prompting actors who devote time and money to this task. Far from restricting the manifestation of thought or of deepening the definition of a judgment of truth, its role would be to reposition the function of the dialogue with information.

Timely the statement by Rafael Lorenzo-Fernandez Koatz who, although was not analyzing the prospect of misinformation, it is well suit in concluding on the limits of freedom of expression:

\begin{abstract}
In our view, the best way to minimize intolerance is by arguing, shedding light on the irrationality of their theses, and presenting their advocates so that public opinion can know, criticize, and morally repudiate them. We need to dialogue with these people, face their arguments, not because they deserve it, but to demonstrate to the other listeners the misconceptions of the positions they stand for. The solution to the minimization of these social ills is therefore to adopt public educational policies aimed at the inclusion of minorities and the adoption of cultural diversity and mutual respect for the differences of our pluralistic and multicultural society. An interesting example that can be given, in this sense, is the children's book What I Like About Me, written by Allia Zobel-Nolan, published by Caramelo, which seeks to teach children to live with the difference of race, creed, physical characteristics, etc. Such initiatives should be encouraged by the public authorities in all spheres." (2017, p.16).
\end{abstract}

So it is not just a question of encouraging checking agencies or promoting selfchecking. After all, the check also goes through a judgment of what would be the truth about certain facts. In this regard, it is not irrelevant the discussion on the bias that checking agencies are also capable of propagating. Much has been discussed - and

\footnotetext{
${ }^{46} \mathrm{An}$ analysis of the perspective of Ronald Dworkin's work, but one that will be dealt with in another work, is timely: "Understanding what types of concepts they are and what kind of arguments we need will help us to construct and test the conceptions of judicial accountability , life, moral obligation, human rights, freedom, equality, democracy and law" (DWORKIN, 2012, p. 172).
} 
is still being discussed - in traditional media. There were no few occasions when long before the Internet - candidates were fined and even banned (from running) for abusive use of the media.

What is least relevant in this proposal is the one-sided choice of history with the definition of what would be false or true. Misinformation cannot be a point of view that we consider to be wrong or something that is in the sphere of debate. Nor does it correspond to the search for an absolute truth to reveal an authoritarian thinking. ${ }^{47}$

The key point is to deliver (or give back) citizens the capacity and instrumentality necessary for them to be able to consider another version of the facts, to analyze them and to make their own judgement. Far from a judge of truth, be it public, private or owner of one of the communication platforms.

The challenge of our time, therefore, is how to exploit this pretension of making the practice of dialogue in contradiction with the information increasingly disseminated. Seeking current tools that are capable of assisting in this task, it is questioned whether the state fomentation would not be an instrument capable of creating incentive models.

Fomentation is one of the institutes of Administrative Law without a single conceptualization and that suffers of little doctrinal attention in Brazil. Generally, it would be the "administrative activity to encourage private initiative of public utility" (DI PIETRO, 2016, p.87), with state "aid" or "support" being one of the pillars of the institute, directed towards a private activity (SILVA, 2018, in press).

Some significant points seem to point to the adequacy of the institute in a question so sensitive to state interference. Through it, the Public Power induces the execution of an activity of public relief with a private individual. Therefore, Pozas (1949, p.46) establishes a cut-off between the development and, for example, public services,

\footnotetext{
47 The search for absolute truth usually leads to authoritarian governments, as Jay Martin warns: "for ironically, truth-telling can under certain circumstances be a weapon of the powerful, while lying is a tactic of the weak. And the politician who doggedly follows his moral convictions, embracing what Weber famously called a Gesinnungsethik (ethic of ultimate ends), may ultimately do more harm than one who practices a Verantworthungsethik (ethic of responsibility). Convictions, after all, is an ambivalent virtue when compromise and flexibility may better serve the common good. For it may be fueled more by the desire - dare we call it self-serving? - to save one's soul than to save the world. This is not a brief for cynicism or immorality nor a justification of winning 'by any means necessary', let alone an exhortation to give up entirely the desire to know what is the truth (at least to the extent politics include that quest). It is just a sober recognition that politics, however we choose to define its essence and limit its contours, will never be an entirely fib-free zone of authenticity, sincerity, integrity, and righteousness. And maybe, I hope it will be clear by now, that's ultimately a good thing too" (2010. p. 180 apud NEISSER, 2016. p. 38).
} 
given that in public services the Public Power would act "directly and with its own means the ends pursued", while, in the fomentation, its purpose would be to "encourage individuals" to develop an activity of interest to the Administration.

Moreover, the fomentation, is voluntary, not mandatory, which would serve to differentiate it from the power of administrative police: "while it prevents and represses, the fomentation protects and promotes without making use of coercion" (POZAS, 1949 , pp. 46) $)^{48}$.

Another relevant aspect about the institute lies in the public interest present in the activities supported by the State. These activities should generate beneficial effects on citizens, even to justify the support or aid given by State.

Apparently, faced with this menu of alternatives, there would not be a single and unique means capable of solving the challenge of misinformation. All efforts must work together to meet this challenge of the new era, with and without the participation of the State.

\section{CONCLUSION}

To answer whether the paradigm shift caused by the new technologies attracts some new or reaffirms the somewhat old role of the State in the fight against misinformation, especially in the elections, is not a simple task.

The research revealed that, without the claim to exhaust the subject, misinformation was not treated as a central object of concern in the electoral process, despite the prohibitions on the dissemination of untrue facts until the emergence of new technologies.

The data tend to reveal that on the subject of misinformation, the attention of the control was focused on the protection of individual rights. The restriction on the

\footnotetext{
${ }^{48}$ Thus, in the final analysis, Pozas defines the promotion as: "la acción de la Administración encaminhada a proteger y promover aquellas actividades, establecimientos o riquezas debidos a los particulares y que satisfacen necesidades públicas o se estiman de utilidad general, sin usar de la coacción ni crear servicios públicos" (1949. p. 46).
} 
disclosure of facts that were known to be untruthful or false propaganda tended more to the right of reply, to the protection of image and honor than to freedom of vote.

The freedom of the vote had, as a focus of protection, the fight against the abusive use of the media, the abuse of political power and economic power (in all its aspects).

In spite of the will of the voter to be formed by a universe of complexities, it cannot be denied that new technologies have the potential to influence the freedom of voting, just as traditional media have always had. And the centrality of the electoral process used by the vote leads to the conclusion that the autonomy of the will, in this sphere, cannot be treated under the same parameters of daily life. The new instruments, it seems, tend to deepen this damage, considering the dissemantion of platforms, content producers and the speed of information circulation.

Given the result, the alternatives to deal with this new scenario of misinformation must be conjugated. And in this challenge, the state must reposition its role beyond the jurisdictional function and the duty to develop a public education policy. It also has the duty to instrumentalize the pretension of making everyday practice and the practice of dialogue in contradiction with the increasingly disseminated information that reaches the voter.

One approach proposed in this article would be to use an old tool of Public Administration that was not the subject of major studies (at least in Brazil): the fomentation. Through the fomentation, the State would encourage actions aimed at expanding voter's capacity for dialogue with all the information it receives, without giving any actor the role of absolute judge of truth.

\section{REFERENCES}

ALLCOTT, Hunt; GENTZKOW, Matthew. Social Media and Fake News in the 2016 Election. Journal of Economic Perspectives, v. 31, n. 2, p. 211-236, primavera 2017. Disponível em: $<$ https://www.jstor.org/stable/44235006?seq=1\#page_scan_tab_contents>. Acesso em 20 fev. 2018.

ALVIM, Frederico Franco. Cobertura política e integridade eleitoral: efeitos da mídia sobre as eleições. Florianópolis: Habitus, 2018. 
ARISTÓTELES. Política, VI, 1. Brasília: Editora Universidade de Brasília, 1985.

BBC News. Facebook ditches fake News warning flag, 21 dez. 2017. $<$ https://www.bbc.com/news/technology-42438750>. Acesso em 29 jul. 2018.

BOBBIO, Norberto. Teoria Geral da Política. 20ํㅡㄴ Tiragem.Rio de Janeiro: Elsevier, 2000.

BRASIL. Código Eleitoral, Lei no 4.737 de 15 julho de 1965. Disponível em: <http://www.planalto.gov.br/ccivil_03/LEIS/L4737.htm>. Acesso em 17 ago. 2018.

Lei 9.504, de 30 de setembro de 1997. Estabelece normas para as eleições. Disponível em: < http://www.planalto.gov.br/cciviL_03/leis/L9504.htm>. Acesso em 17 ago. 2018.

CONFESSORE, Nicholas; DANCE, Gabriel. Battling fake accounts, Twitter to slash millions of followers. NEW York Times, 11 jul. 2018. Disponível em: <https://www.nytimes.com/2018/07/11/technology/twitter-fake-followers.html>. Acesso em 20 jul 2018.

DAHL, Robert. Sobre a democracia. Tradução de Beatriz Sidou. Brasília: Editora Universidade de Brasília, 2001.

DAHL, Robert. On political equality. New Haven: Yale University Press, 2006.

DI PIETRO, Maria Sylvia. Direito administrativo. 29. ed. Rio de Janeiro: Forense, 2016.

DWORKIN, Ronald. Levando os direitos a sério. 3ª ed. São Paulo: Saraiva, 2010.

FIGUEIREDO, Marcus. A decisão do voto: democracia e racionalidade. Belo Horizonte: Editora UFMG, 2008.

HERN, Alex; Cadwalladr, Carole. Revealed: Aleksandr Kogan collected Facebook users's direct messages. The Guardian.13 abr. 2018. Disponíve em: $<$ https://www.theguardian.com/uk-news/2018/apr/13/revealed-aleksandr-kogancollected-facebook-users-direct-messages >. Acesso em 17 ago. 2018.

MACHADO, Jónatas. Liberdade de expressão: dimensões constitucionais da esfera pública no sistema social. Coimbra: Coimbra Ed. 2002.

MAGALHÃES, José Luiz Quadros de. O Poder Municipal: Paradigmas para o Estado Constitucional Brasileiro. Belo Horizonte: Del Rey, 1999.

JAY, Martin. The virtues of mendacity: on lying in politics. Charlottesville: University of Virginia Press, 2010. 
KELSEN, Hans. De la esencia y valor de la democracia. Tradução de Juan Luis Requejo Pagés. 2. ed. Oviedo: KRK Ediciones, 2009.

NEISSER, Fernando Gaspar. Crime e mentira na política. Belo Horizonte: Ed. Fórum, 2016.

OSÓRIO, Aline. Direito eleitoral e liberdade de expressão. Belo Horizonte: Editora Fórum, 2017.

PATEMANN, Carole. Participation and democratic theory. London: Cambridge University Press, 1970.

SHABAN, Hanza. Facebook says it will start removing posts that may lead to violence. Washington Post, 19 jul.2018. Disponível em:<https://www.washingtonpost.com/technology/2018/07/19/facebook-says-it-willstart-removing-posts-that-may-lead-violence/?noredirect=on>. Acesso em 17 ago. 2018.

SINTOMER, Yves. Démocratie participative, démocratie delibérative: deux catégories emérgentes. In: BACQUÉ, Marie-Hélène; SINTOMER, Yves (Dir.). Démocratie participative: histoire et généalogie. Paris: La Découverte, 2011.

POZAS, Luis Jordana de. Ensaio de uma teoria del fomento en el derecho administrativo. Revista de Estudos Políticos 48, 1949.

POZAS, Luis Jordana de. Ensaio de uma teoria del fomento en el derecho administrativo. Revista de Estudos Políticos 48, 1949. p. 46

RAIS, Diogo (Coord.) RAIS, Diogo; FALCÃO, Daniel; GIACHETTA, André; MENEGUETTI, Pâmela. Direito Eleitoral Digital. São Paulo: Revista dos Tribunais, 2018.

RAIS, Diogo. Fake News e eleições, 2018, no prelo.

ROSEMBERG, Matthew. Helping Cambridge Analytica Harvest Facebook Data. The New York Times, 22 abr. 2018. Disponível em: $<$ https://www.nytimes.com/2018/04/22/business/media/cambridge-analyticaaleksandr-kogan.html>. Acesso em 17 ago 2018.

SARTORI, Giovanni. The Theory of Democracy Revisited. Part two: the classical issues. Chatham: Chatham House Publishers, 1987.

SINTOMER, Yves. O poder do povo: júris de cidadãos, sorteio e democracia participativa. Belo Horizonte: Editora UFMG, 2010.

SILVA, Marco Aurélio Barcelos. Das concessões de fomento no brasil: proposta de regulação consentida da atividade econômica para o fim dos serviços públicos, 2018, no prelo. 